\title{
Effect of Addition of Whey Proteins on the Microstructure and Syneresis of "Suero Costeño” Made from Goat Milk
}

\author{
Diego F. Tirado ${ }^{1}$, Diofanor Acevedo-Correa ${ }^{2}$, Diana C. Mantilla-Escalante ${ }^{3}$ \\ ${ }^{1}$ Department of Chemical Engineering, School of Chemistry, Universidad Complutense de Madrid, \\ Av. Complutense s/n, 28020, Madrid, Spain. \\ e-mail: ditirado@ucm.es. \\ ${ }^{2}$ Research Group Nutrición, Salud y Calidad Alimentaria (NUSCA), Universidad de Cartagena, \\ Campus of Piedra de Bolívar, Cartagena de Indias, Colombia. \\ ${ }^{3}$ Departament of Applied Physical Chemistry, School of Science, Universidad Autónoma de Madrid, \\ C/ Francisco Tomás y Valiente $N^{\circ} 7$, Madrid, Spain.
}

\begin{abstract}
A Colombian Caribbean coast sour creamis a fermented dairy product that is native to and traditionally prepared only in that area, where it is known as "Suero Costeño". On the other hand, many of the properties of dairy products such as Suero Costeño are determined by the spatial arrangement of components including the casein particles that form a protein matrix, the fat globules, dispersed water and minerals. In this work, scanning electron microscopy (SEM) was used to study the effect of the addition of whey proteins on the microstructure and syneresis of Suero Costeño made from goat milk. Through micrographs obtained by a JEOL JSM 820 scanning electron microscope, it was determined that by increasing total solids, pore structure size, and therefore syneresis, decreased due to the interlocking capacity of denatured whey proteins, which increased the degree of binding between protein particles, forming a dense network.
\end{abstract}

Keywords-Sour cream, Scanning Electron Microscopy, Whey protein, Goat milk, Syneresis.

\section{INTRODUCTION}

Although milk is defined as the product of the secretion from mammary glands of mammals, especially cow cattle, there are other animals used for its acquisition, which include goat, buffalo, sheep, camel and llama. Despite the above, milk, regardless of its origin, contains the same nutritional constituents, with variations in composition and properties [1]. The components that vary most are protein and fat [2]. Cow cattle are the most significant milk producer in the world, but in recent years there has been a considerable increase in the production and industrialisation of goat milk [1], and there is a growing interest in research and investment in goat milk in several countries, mainly due to its attractive nutrient content. Regarding that, goat milk has lower lactose content and a higher concentration of total solids (mostly proteins and fats) and nutrients than cow milk [3]-[6]. Fat from goat milk influences positively on sensory properties of food products, more than that from cow milk [5]. Moreover, fat from goat milk is easily digestible due to its ease of dispersion and its natural homogenization by fat globules [5], [7], which exhibit smaller sizes, without the cream being separated by itself [5], [8]. Taken into account the aforementioned, goat milk is considered one of the most suitable types of milk for the production of dairy products [5], [9], [10].

Fermentation is one of the most traditional ways of transforming raw food all over the world. It confers unique characteristics to the matrix, such as the improvement of sensory characteristics, functional properties and increased useful life, given by the dynamics of the microbial community that lives there. Sour cream from the Colombian Caribbean coast is a fermented dairy product that is native to and traditionally prepared in that area from cow milk, where it is known as "Suero Costeño" [5]. It is produced extensively by the rural population of the departments of Antioquia, Córdoba, Sucre and Bolívar, which represents a gastronomic heritage of Colombian cuisine [11]. The sour cream is a final product similar to sour, slightly acidic cream and is generally used as a dressing, accompanying almost all meals [12], and although it is produced industrially, has little acceptance on the part of consumers, because they detect differences in taste between artisan and industrial sour cream, since the latter is produced by pasteurized milk and bacteria used for the manufacture of kumis [13]. In addition to this, the industrially produced one presents syneresis; which is a process of separating whey from curd, simultaneously with its shrinkage and is the most significant defect that affects the quality of dairy products, where the liquid is observed on the surface of the product causing consumer rejection [13]. These quality problems have been addressed by increasing fermentation time and adding thickeners, which increases 
costs and makes the product more perishable [14], making it necessary to find new mechanisms that help improve the structure of the final product while reducing defects such as syneresis.

The syneresis is produced by the shrinkage of the gel without applying external forces and is due to the instability of the net, which results in the loss of the ability to trap the liquid phase. Gel shrinkage coincides with liquid expulsion or whey separation. The presence of liquid on the surface is a defect in fermented dairy products [15]. The main causes of syneresis are: low total solids content, high incubation temperatures, excessive heating of the milk, rapid acidification rate, movement or agitation during gel formation and minimal acid production, with $\mathrm{pH}$ higher than 4.8 [16], so an adjustment in its solids could mean a contribution to the improvement in its structure and reduction in defects such as syneresis.

Many of the properties of dairy products, such as sour cream, are determined by the spatial arrangement of components including the casein particles that form a protein matrix, the fat globules, dispersed water and minerals. The arrangement of these components on the micron scale is known as the microstructure of sour cream. Changes in process conditions or the choice of ingredients can alter the microstructure of the product considerably and thus its final functional properties. The ability to image and characterise these changes will provide an essential tool for the quality control of sour cream and other dairy products [17]. Regarding that, scanning electron microscopy (SEM) was introduced into food research in 1960 and is currently used to study the microstructure of food, taking advantage of signals obtained from secondary electrons produced by the interaction between an electron beam and the sample, getting a three-dimensional image with great depth of field [16].

Whey contains more than half of the solids present in the original milk, including about $20 \%$ of proteins, most of the minerals, lactose and soluble vitamins [18]. For the food industry, whey is an economical source of protein, which provides multiple application properties in a wide range of foods due to its diverse functional capabilities. Whey products improve texture, enhance taste and colour, have emulsifier and stabiliser characteristics, improve flow properties, among other techno-functional properties, which makes it possible to increase the quality of many food products [18]. Considering the aforementioned, it is believed that the increase of total solids with partially demineralized whey is a strategy to decrease syneresis in the whey made from goat milk, therefore this work used the scanning electron microscopy (SEM) to study the effect of the addition of whey proteins on the microstructure and syneresis of the sour cream from the Colombian Caribbean coast, also known as Suero Costeño, made from goat milk.

\section{MATERIALS AND METHODS}

\section{A. Preparation of the sour cream at different levels of total solids}

The sour cream was elaborated using the same proposed by Tirado et al., [5]. Goat milk from Bolívar (Colombia) was standardised to reach a $12 \%$ of total solids (Control). On the other hand, partially demineralised whey was added to achieve concentrations of $14 \%$ and $16 \%$ of total solids. Pasteurization was performed at $336.15 \mathrm{~K}$ for $30 \mathrm{~min}$. Lactobacillus paracasei and Lactococcus lactis were then added and incubated at $30^{\circ} \mathrm{C}$ for $12 \mathrm{~h}$ until a pH of 4.6 and an average acidity of $104.8 \mathrm{Th}$ were reached. Then, it was filtered, and the whey was separated from the milk clot. Sodium chloride was added to the clot to confer consistency to the product. The material was subsequently packed in plastic bags and stored at $277.15 \mathrm{~K}$ for $24 \mathrm{~h}$

\section{B. Scanning electron microscopy}

Analyses were performed in triplicate for each formulation of sour cream. The samples were taken at $4 \mathrm{~cm}$ below the surface and the whey was removed by centrifugation at 3000rpm, then fixed for $12 \mathrm{~h}$ in a buffer solution at $2.5 \%$ glutaraldehyde at $\mathrm{pH} 7.2$ with $0.1 \mathrm{M}$ phosphate, then washed for $2 \mathrm{~h}$ to $3 \mathrm{~h}$ with the same buffer solution, then post-fixed in $1 \%$ osmium tetroxide for $1 \mathrm{~h}$, then dehydrated in series of ethanol solutions with a volume fraction of $25 \%, 50 \%, 70 \%, 80 \%, 90 \%$ and $100 \%$. Later, it was dried with $\mathrm{CO}_{2}$ for 2 hand placed in a sample holder, coated with a palladium-gold layer of $35 \mathrm{~nm}$ in an evaporator. Samples were placed in boxes with silica gel. Micrographs were obtained in a JEOL JSM 820 Scanning Electron Microscope (JEOL Ltd, Japan) with a voltage acceleration of $10 \mathrm{KV}$. Samples were photographed at magnifications of 4000X and 8000X, in polaroid films type 52 .

\section{RESULTS AND ANALYSIS}

Fig. 1 shows the microstructure of the sour cream prepared with $12 \%$ of total solids. The protein network was rough, less dense, opened and with empty spaces as a result of the fusion of small casein aggregates, this was due to the low amount of proteins, which prevented the formation of bonds that made the matrix formed more compact and stable [5]. For this sour cream, the structure was a network of proteins formed by chains and aggregates, of casein micelles. This aggregation was because the isoelectric $\mathrm{pH}$ of milk proteins was reached in 
globular form, with empty spaces, and where Lactobacillus paracasei were readily distinguished. Fat globules were embedded in the protein network as shown in Fig.1.

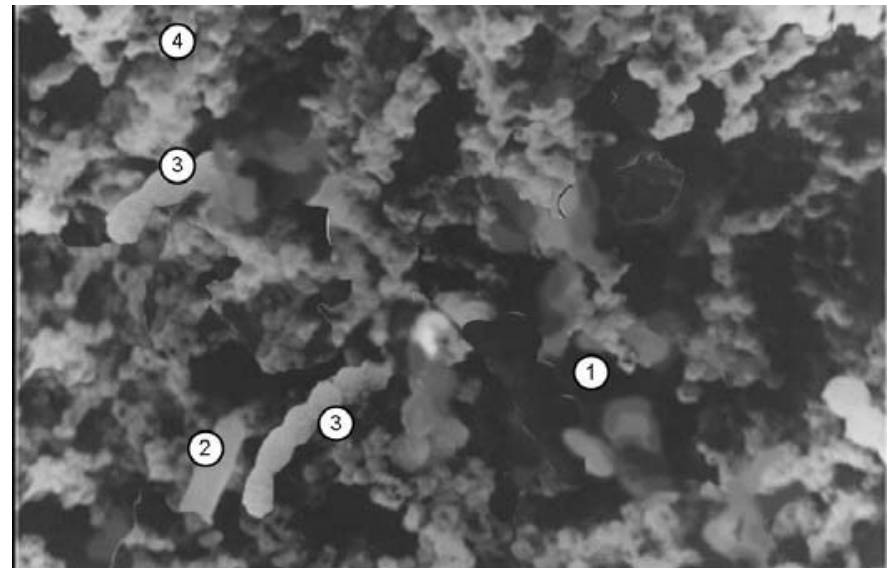

a)

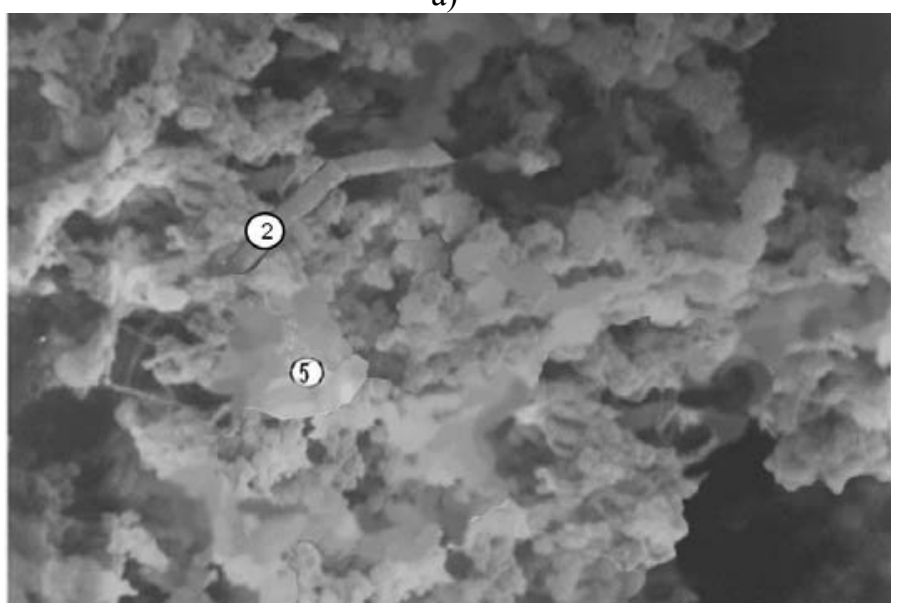

b)

Fig. 1. Micrograph of sour cream with $12 \%$ of total solids (Control). (1) empty spaces, (2) Lactobacillus paracasei, (3) Lactococcus lactis, (4) casein networks and (5) fat globules.

Scanning electron microscopy at 4000X and 8000X indicated that sour cream gels made with low total solids (proteins) had large pores and high syneresis, but as total solids were increased they had a fine structure, the size of aggregates and pores became small, and the network of dense crosslinking and syneresis decreased, as they became smaller as shown in Fig. 2 and Fig. 3. It was evidenced that the fortification with whey proteins and their homogenization was useful in the reduction of syneresis, because whey proteins were associated with casein micelles after thermal treatment and acted as binding material [19].Casein micelles were mainly bound by particle-particle bonds in large chains, with small spaces, rather than by fusion of aggregates. Similar results were reported by Lee and Lucey [16] for yoghurt gels.

The filamentous appearance of the protein network was due to whey proteins on the surface of the micelle. Aggregates of casein micelles in chains were bound by whey proteins because denatured $\beta$-lactoglobulin interacted with K-casein through disulphide bonds [20]. An essential consequence of the formation of this complex was the possibility of binding other casein particles by interaction with other whey proteins denatured with casein micelles [21]. The forces of interaction determine the consistency and physical stability of the gel, because the increase in total solids content in the sour cream produced an increase in consistency coefficient and yield threshold, while decreasing the rate of flow behaviour, since during thermal treatment, the proteins of the whey partially demineralized by its water retention capacity, form disulphide bonds with the caseins, making the structure more compact [22].

On the other hand, according to Acevedo et al., [23], in their study of the effect of process variables on acidification kinetics, the viability and syneresis of sour cream indicated that syneresis rises as the temperature increases and decreases when total solids increase, although the syneresis increases slightly when the fermentation temperature increases. It should be noted that the rise in temperature increases the syneresis speed, due to the relaxation of the bonds and the denaturing of the proteins that form the casein network [24]. Water retention capacity and syneresis decrease when the protein content of total solids was increased, as well as the increase in whey proteins in the whey/casein ratio, decreased syneresis [25]. 


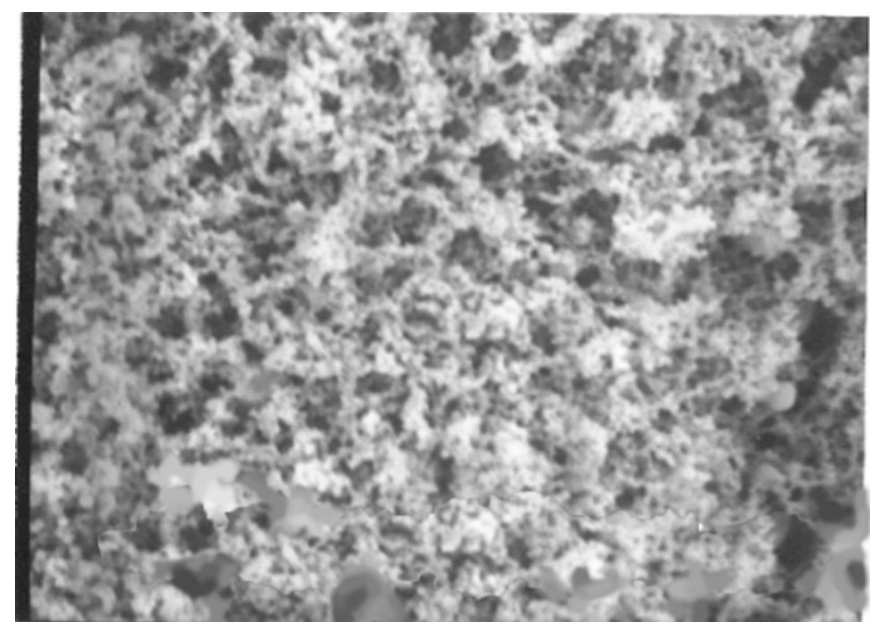

Fig. 2. Micrograph of sour cream with $14 \%$ of total solids

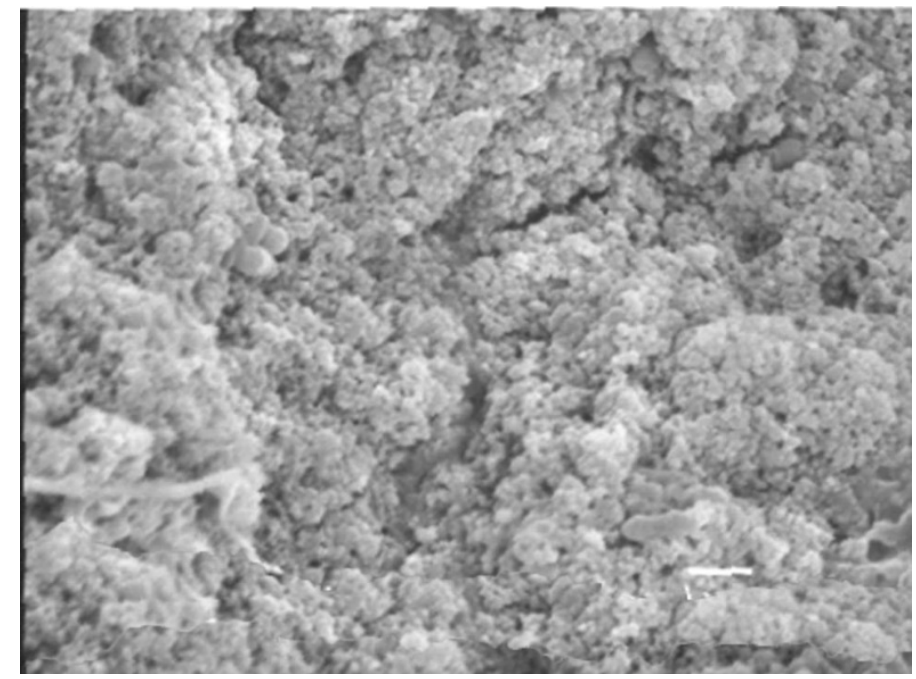

Fig. 3. Micrograph of sour cream with $16 \%$ of total solids

\section{CONCLUSIONS}

By scanning electron microscopy was possible to establish the relationships between processing, microstructure and syneresis. The increase in total solids decreased the size of the structure pores and therefore the syneresis, due to the cross-linking capacity of denatured whey proteins, which increased the degree of binding between protein particles allowing a dense network. This kind of work shows contributions for the optimisation of production processes of the sour cream, aimed at obtaining high-quality products for consumption. Finally, evidence was found that the fortification with whey proteins and their homogenization was useful to reduce syneresis because whey proteins are associated with casein micelles after heat treatment and act as binding material.

\section{ACKNOWLEDGMENT}

The authors are grateful to the Universidad de Cartagena for the financial support that was granted to the Research Group Nutrición, Salud y Calidad Alimentaria (NUSCA) in the call 'Séptima convocatoria para la financiación de proyectos de investigación, para grupos de investigación visibles (categorizados o reconocidos) en la plataforma Sienti del Departamento Administrativo de Ciencia, Tecnología e Innovación COLCIENCIAS'. 


\section{REFERENCES}

[1] C. Granados, L. A. Meza, R. S. Paba, and D. Acevedo, "Layer Cheese made from Buffalo Milk in The Municipality of Carmen de Bolívar (Colombia)," Información Tecnológica, vol. 25, no. 6, pp. 39-44, 2014.

[2] O. A. Sbodio, E. J. Tercero, M. S. Zannier, and G. R. Revelli, "Thermally Treated Milk: Influence of pH and CaCl 2 on Cuartirolo Cheese-Making," Informacion tecnológica, vol. 21, no. 5, pp. 107-116, 2010.

[3] P. G. Toral, Y. Chilliard, J. Rouel, H. Leskinen, K. J. Shingfield, and L. Bernard, "Comparison of the nutritional regulation of milk fat secretion and composition in cows and goats," Journal of Dairy Science, vol. 98, no. 10, pp. 7277-7297, 2015.

[4] D. Cais-Sokolińska, J. Wójtowski, J. Pikul, R. Danków, M. Majcher, J. Teichert, and E. Bagnicka, "Formation of volatile compounds in kefir made of goat and sheep milk with high polyunsaturated fatty acid content," Journal of Dairy Science, vol. 98, no. 10, pp. 6692-6705, 2015.

[5] D. F. Tirado, A. Vertel-Gallego, J. Lora-Sánchez, L. A. Gallo-García, D. Acevedo, and R. Torres-Gallo, "Rheological properties of Colombian-Caribbean-coast sour cream from goat milk," International Journal of Food Science \& Technology, p. DOI 10.1111/ijfs.13562, 2017.

[6] D. F. Tirado, D. Acevedo, and P. M. Montero, "Goat Milk Whey Protein Extraction by Applying Pulsed Electric Fields of High Intensity (PEF),” Información Tecnológica, vol. 26, no. 5, pp. 71-80, 2015.

[7] J. Miocinovic, Z. Miloradovic, M. Josipovic, A. Nedeljkovic, M. Radovanovic, and P. Pudja, "Rheological and textural properties of goat and cow milk set type yoghurts," International Dairy Journal, vol. 58, pp. 43-45, 2016.

[8] Y. W. Park, "Rheological characteristics of goat and sheep milk," Small Ruminant Research, vol. 68, no. 1, pp. 73-87, 2007.

[9] M. Moreno-Montoro, M. Olalla, R. Giménez-Martínez, T. Bergillos-Meca, M. D. Ruiz-López, C. Cabrera-Vique, R. Artacho, and M. Navarro-Alarcón, "Ultrafiltration of skimmed goat milk increases its nutritional value by concentrating nonfat solids such as proteins, Ca, P, Mg, and Zn," Journal of Dairy Science, vol. 98, no. 11, pp. 7628-7634, 2015.

[10] F. P. Bruzantin, J. L. P. Daniel, P. P. M. da Silva, and M. H. F. Spoto, "Physicochemical and sensory characteristics of fat-free goat milk yogurt with added stabilizers and skim milk powder fortification," Journal of Dairy Science, vol. 99, no. 5, pp. 3316-3324, 2016.

[11] K. E. Motato, C. Milani, M. Ventura, F. E. Valencia, P. Ruas-Madiedo, and S. Delgado, "Bacterial diversity of the Colombian fermented milk 'Suero Costeño' assessed by culturing and high-throughput sequencing and DGGE analysis of 16S rRNA gene amplicons," Food Microbiology, vol. 68, pp. 129-136, Dec. 2017.

[12] D. Acevedo, C. Granados, and R. Torres, "Rheological characterization of a Fermented Milk Product known as Suero Costeño from Turbaco, Arjona, El Carmen de Bolívar and a Commercial Product (Colombia)," Información Tecnológica, vol. 25, no. 3, pp. 3-10, 2014.

[13] D. Acevedo, A. Rodriguez, and A. Fernandez, "Low amplitude oscilatory determinationsfor suero costeño," Revista U.D.C.A Actualidad \& Divulgación Científica, vol. 15, no. 1, pp. 219-225, 2012.

[14] C. Granados, D. Acevedo, and R. Torres, "Quality of milk and of Suero Costeño (whey) from Turbaco, Arjona and Carmen de Bolívar - Colombia.," Revista Lasallista de investigación, vol. 9, no. 2, pp. 132-137, 2012.

[15] J. A. Lucey, M. Tamehana, H. Singh, and P. A. Munro, "Effect of heat treatment on the physical properties of milk gels made with both rennet and acid," International Dairy Journal, vol. 11, no. 4-7, pp. 559-565, Jul. 2001.

[16] W. J. Lee and J. A. Lucey, "Formation and Physical Properties of Yogurt," Asian-Aust. J. Anim. Sci, vol. 23, no. 9, pp. 1127-1136, 1998.

[17] L. Ong, R. R. Dagastine, S. E. Kentish, and S. L. Gras, "Microstructure of milk gel and cheese curd observed using cryo scanning electron microscopy and confocal microscopy," LWT - Food Science and Technology, vol. 44, no. 5, pp. 1291-1302, Jun. 2011.

[18] D. Acevedo, J. D. . Jaimes, and C. R. Espitia, "Effect of the Addition of Whey to Kneaded Coastal Cheese," Información Tecnológica, vol. 26, no. 2, pp. 11-16, 2015.

[19] M. J. Torres-Llanez, B. Vallejo-Cordoba, M. E. Díaz-Cinco, M. A. Mazorra-Manzano, and A. F. González-Córdova, "Characterization of the natural microflora of artisanal Mexican Fresco cheese," Food Control, vol. 17, no. 9, pp. 683-690, Sep. 2006.

[20] M. Saarela, G. Mogensen, R. Fondén, J. Mättö, and T. Mattila-Sandholm, "Probiotic bacteria: safety, functional and technological properties," Journal of Biotechnology, vol. 84, no. 3, pp. 197-215, Dec. 2000.

[21] J. . Lucey, M. Tamehana, H. Singh, and P. . Munro, "A comparison of the formation, rheological properties and microstructure of acid skim milk gels made with a bacterial culture or glucono- $\delta$-lactone," Food Research International, vol. 31, no. 2, pp. 147-155, Mar. 1998.

[22] D. Acevedo, A. Rodriguez, and A. Fernandez, "Simultaneus effects of the process variables on the rheological properties os suero costeño," Biotenología en el sector agropecuario e industrial, vol. 2, no. 2, pp. 112-117, 2013.

[23] D. Acevedo, A. Rodríguez, and A. Fernández, "Effect of the Process Variables on the Kinetics of Acidity, Viability and Syneresis of the Colombian Coastal Whey," Informacion tecnológica, vol. 21, no. 2, pp. 29-36, 2010.

[24] M. Castillo, J. A. Lucey, T. Wang, and F. A. Payne, "Effect of temperature and inoculum concentration on gel microstructure, permeability and syneresis kinetics. Cottage cheese-type gels," International Dairy Journal, vol. 16, no. 2, pp. 153-163, Feb. 2006.

[25] F. Remeuf, S. Mohammed, I. Sodini, and J. . Tissier, "Preliminary observations on the effects of milk fortification and heating on microstructure and physical properties of stirred yogurt,” International Dairy Journal, vol. 13, no. 9, pp. 773-782, Jan. 2003.

\section{AUTHOR PROFILE}

Diego F. Tirado is a $\mathrm{PhD}$ student in Chemical Engineering at the Universidad Complutense de Madrid (Spain). Mr. Tirado has a bachelor degree in Food Engineering and a master degree in Environmental Engineering from the Universidad de Cartagena (Colombia).

Diofanor Acevedo-Correa works as a full-time professor at the Universidad de Cartagena. Dr. Acevedo has a doctoral degree in Food Engineering from the Universidad del Valle (Colombia). Furthermore, he has bachelor degrees in Food Engineering and Pharmaceutical Chemistry from the Universidad de Cartagena. He is full-time researcher of the Research Group Nutrición, Salud y Calidad Alimentaria (NUSCA).

Diana C. Mantilla-Escalante is a PhD student in Food Sciences at the Universidad Autónoma de Madrid (Spain). Mrs. Mantilla-Escalante has a bachelor degree in Food Engineering from the Universidad de Cartagena and a master degree in Novel foods from the Universidad Autónoma de Madrid. 